\title{
Karnavas Bezi
}

\section{Karnavas Fabric}

\section{Ayșe Aslıhan Eroğlu}

Prof. Dr., Atatürk Üniversitesi, Güzel Sanatlar Fakültesi, Geleneksel El Sanatları Bölümü email: aaslihanerguder@atauni.edu.tr (DORCID ID: https://orcid.org/0000-0002-0320-3300

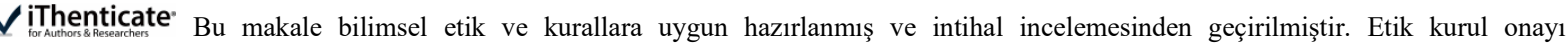
gerektirmemektedir.

Atıf (APA 7)/To cite this article

Eroğlu, A. A. (2021). Karnavas bezi. Atatürk Üniversitesi Güzel Sanatlar Enstitüsü Dergisi, 27 (47), $443-452$. https://doi.org/10.35247/ataunigsed.987381

Makale Gönderim Tarihi/Received: 26/08/2021

Makale Kabul Tarihi/Accepted: 09/09/2021

Makale Yayın Tarihi/Published: 28/10/2021

Research Article / Araștırma Makalesi

Öz

Karnavas bezi Erzurum İli Olur İlçesi Ormanağzı Köyü’nde dokunur ve adını köyün eski adı olan Karnavas 'tan alır. Karnavas, dokuması ile kültürel kimliğini oluşturmuş yörelerinden biridir. Karnavas bezi ve cecimi yöreye özgü karakteristik özellikler gösterir. Sadece bu köyde dokunan Karnavas bezi, köy kadınları tarafindan başörtüsü olarak kullanılmaktadır. Yörenin dokumacılıkla ilgisi eski dönemlere kadar uzanmaktadır. Geçmişte dokumalarda yün kullanılırken, pamuğun bölgeye gelmesiyle pamuklu dokumaya geçildiği eski sandıklardan çıkan yün dokuma Karnavas başörtülerinden anlaşılmaktadır. Boyalar eskiden doğal malzeme ve bitkilerden elde edilmișse de günümüzde suni boyalar kullanılmaktadır.

Abstract

Karnavas fabric is woven in Ormanağzı Village of Olur District of Erzurum Province and takes its name from Karnavas, the old name of the village. Karnavas is one of the regions that formed its cultural identity with its weaving. Karnavas fabric and cecimi show characteristic features of the region. Karnavas fabric woven only in this village is used as a headscarf by the women of the village. The region's interest in weaving dates back to ancient times. While wool was used in weaving in the past, it is understood from the wool-woven Karnavas headscarves that came out of the old chests that cotton was used in the region with the arrival of cotton. Although dyes were obtained from natural materials and plants in the past, artificial dyes are used today.
\end{abstract}

Anahtar kelimeler: Karnavas Bezi, Erzurum, Dokuma, Örtü
Keywords: Karnavas Fabric, Erzurum, Weaving, Cover

\section{Giriş}

Erzurum un eski adlarından birisi de "Kal1-Kala" / "Halı Şehri" olarak bilinmektedir. Olur isminin Dede Korkut Hikayeleri'nde geçen Salyur (Salyu) Türk boyunun değişik şekilde söylenişi olduğu da ileri sürülmektedir (Olur ilçesinin en eski adının Tavusker olduğu, bu ismin ise Kafkasya'da Demirkapı ve Derbent kesimlerinde yaşayan Saka-İskit Türk boylarından biri olan Ta-ok'lardan geldiği söylenmektedir. Önceleri bu Türk boyunun yaşadığ 1 alan Dav-eli veya Taveli dendiği, daha sonraları Tahoskar, zamanla da Tavusker şeklini aldı ̆̆ı rivayet edilmektedir (Salman, 2011, s. 51). Kökleri Orta Asya'ya dayanan Türk kavimlerinin Anadolu da dokuma kültürünü zenginleştirerek devam ettirdikleri görülmektedir. Tarihte birçok medeniyete ev sahipliği yapmış Erzurum; Anadolu ile Kafkaslar, Orta Asya arasında adeta kültür köprüsü olmuştur. Bu sebeple de birçok alanda kültür mirası eser ve değer günümüze kadar ulaşmıştır. Bu kültür mirası izlerini Olur ilçesi Ormanağzı (Karnavas) mahallesinde dokunan Karnavas Bezi ve Olur cicimlerinde görmek mümkündür. Söz konusu Olur İlçesine bağlı Ormanağzı (Karnavas) köyünde dokunuyor olması, bu el sanatı bezin Karnavas Bezi olarak adlandırılmasına sebep olmuştur.

Osmanlı devletinin son 200 yıllık döneminde ortaya çıktığı kabul edilen bu değerli el sanatı ürünü, tarih boyunca birçok alanda kullanılmış, Atabekler yurdu olarak bilinen bölgenin o dönemlerde dokuma ihtiyacını karşılamış ve yöre halkı için önemli bir gelir ve geçim kaynağı olmuştur. İlk dönemlerden bu zamana kadar kadınların takribi $76 \times 180 \mathrm{~cm}$. boyutunda olan Karnavas bezini başörtüsü olarak kullandıkları bilinmektedir (Çomaklı, 2008, s. 177). Komşu gezmelerine giderken evli olanların tülbentlerinin üzerine enine tek kat olarak omuzlarını örtecek şekilde aldıkları ve adına 'çit' denen kırmızı veya mavi tonda bir kumaşla başa tutturdukları görülür (Görsel 8). Bekar olanların ise başörtüsünü iki kat yaparak omuzlarını kapatacak şekilde örtündükleri bilinir. Fakat bu durum günümüz bekarlarında gözlenmemektedir. Bu örtünme şekilleri o dönem evli ve bekar hanımların ayırt edilmesini sağlamıştır. Karnavas bezi ilk dönemlerde yünden yapıldığı, pamuğun bölgeye gelmesiyle pamuklu dokumaya geçildiği eski sandıklardan çıkan yün dokuma Karnavas başörtülerinden anlaşılmaktadır. Yöre halkı yün dokumadan pamuklu dokumaya geçmiş olsa da renk ve motiflerini bırakmamış, pamuklu dokumaya aktarmıştır. Karnavas bezi motif ve renk çeşitliliği ile Erzurum dokuması olan Ehram'dan ayrılır.

Karnavas Bezi Türk Kültürünün çok derin anlamlarını ve duygularını yansıtır. Geçmişte kadınlar dile dökemedikleri duygularını dokumalarda kullanılan motiflere yansıtırlardı. Karnavas kadınları da çeyizlerine 4050 adet Karnavas Bezi’nden dokudukları başörtülerini gittiği evin kadınlarına çeyizinden çıkararak hediye ederlerdi. Dokuma da kullanılan motiflerin anlamları göz önüne alındığında gelinin; 'evinize bereketle geldim, 
neslinize yeni nesiller katmaya geldim. Allah bizi nazarlardan korusun” düşüncesini taşıdığı anlaşılmaktadır. Yeni gelinlerin bu dokumayı dokuyarak yeni evlerine gitmeleri iyi dileklerle aileye katılmalarının somut örneği olarak görülebilir.

\section{Yöntem}

Araştırma Betimsel modele dayalı nitel bir araştırmadır. Konu ile ilgili literatür taraması yapılarak, Karnavas bezi ve üretimi ile ilgili bilgiler yerinde gözlem tekniğine dayalı olarak elde edilmiştir.

\section{Bulgular}

\subsection{Karnavas Bezi’ nde Kullanılan Malzemeler}

\subsubsection{Tezgâh}

Karnavas bezi son 50 yıla kadar el tezgahlarında dokunurken günümüzde kamçılı tezgâhta bezayağı tekniği ile geleneksel motifler kullanılarak dokunmaktadır (Görsel 1). Yörede dokuma yapılan tezgahlara "kuy" adı verilmektedir.

\section{Görsel 1}

Karnavas Köyü’nde 100 Yıllık Tezgâh

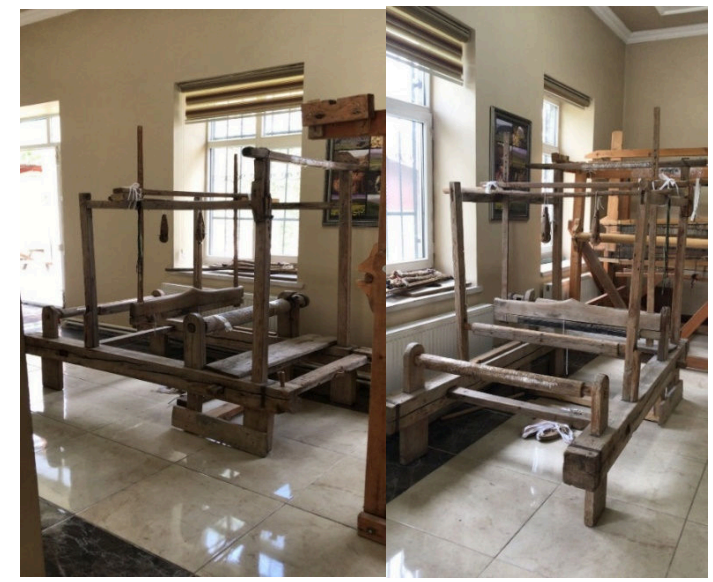

(Keskin, 2021)

\section{Görsel 2}

Kamçılı Tezgâh

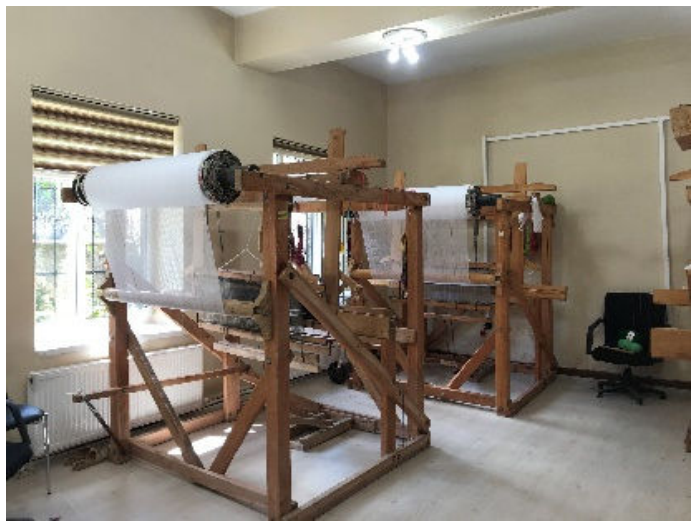

(Eroğlu, 2021)

\section{2. Íplik}

Eskiden dokumacılığıyla ünlü çok iyi kalite ehram, yer sergisi, yük örtüsü, kadınlarda yöresel örtülerin yapımında el eğirmesi yün iplikler uygulanmıştır. Günümüzde fabrikalardan hazır elde edilen pamuk ipliği kullanılmaktadır. Karnavas bezi, atkı ve çözgü iplikleri pamuk veya yün olan bir yöresel dokumadır. Yörede hayvancılığın gelişmiş olması yünden dokunmuş ürünlerin ortaya çıkmasına sebep olmuştur. Karnavas bezinin ilk örnekleri el eğirmesi yün ipliktendir. Yörede dokumada kullanılan iplerinin Oltu’nun Orucuk Köyü’nde eğrildiği kaynaklarda belirtilmektedir. Yöre kadınları yün ipliğin üretiminin zor olması nedeniyle yün dokumayı terk ederek çile halinde 
satın alabildikleri pamuğa geçmiştir (Görsel 3). O dönem çile halinde alınan pamuk ipler, önceden kazanlarda kaynatılır, un ve su (haşil) karışımına batırılır, çileler kazan içerisinde fazla bekletmeden çıkarılır. Islak şekilde yüğlüklere geçirilir, sonra da masuralara sarılırak çözgüye hazırlanır. Bir gün bekletildikten sonra çözgüye alınan pamuk ipler leventlere sarılarak dokuma tezgahlarına asılır, tarak-kücü (tahar işleme) alınır ve dokuma aşamasına geçilir.

\section{Görsel 3}

Karnavas Bezi Iç̧in Çile Şeklinde Pamuk İpi

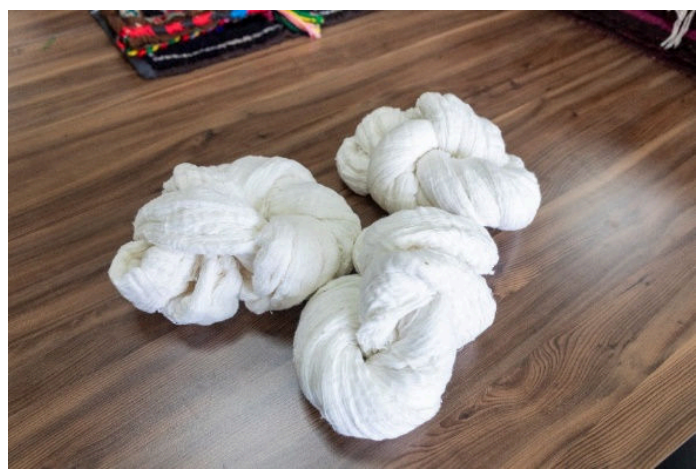

(Eroğlu, 2021)

\section{Görsel 4}

Iplik Yapımında Kullanılan Teşi

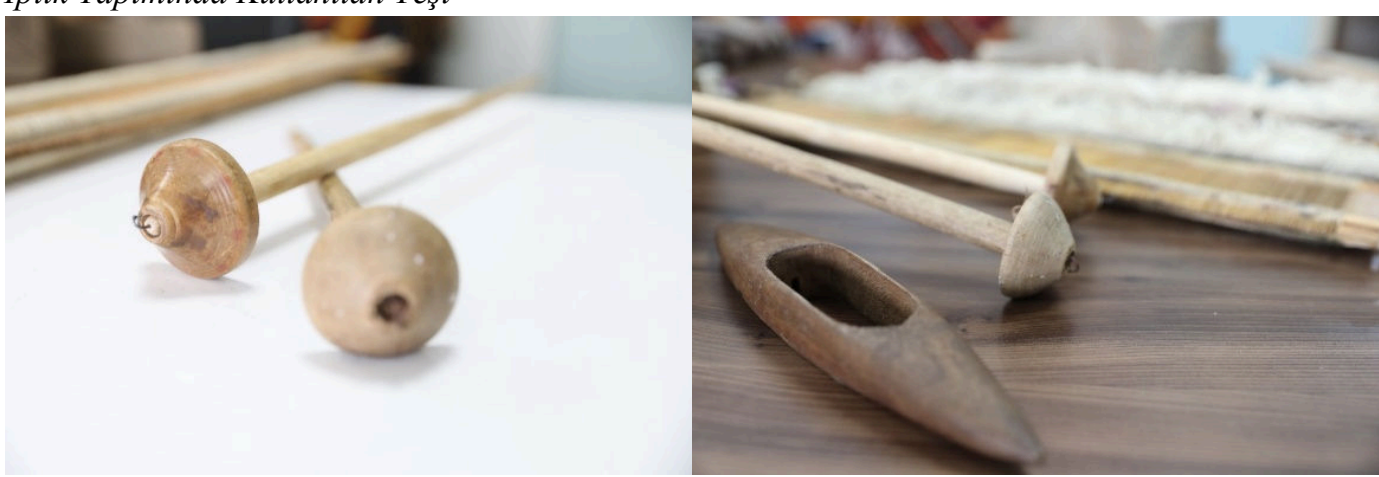

(Eroğlu, 2021)

\section{3. Çıkrık}

İplik yapımında kullanılan “çıkrık”, Türkler tarafından “çığri” olarak adlandırılıyordu. Eski Türkçede çığrı'nın “değirmen”, “çark”, “dolap” gibi isimlendirilen ip çıkrı̆̆ı ve her türlü makara anlamına gelmektedir (Görsel 5-6).

\section{Görsel 5}

Yörede “Dolap” Adı Verilen İliğin Çile Haline Getirilmesini Să̆layan Araç
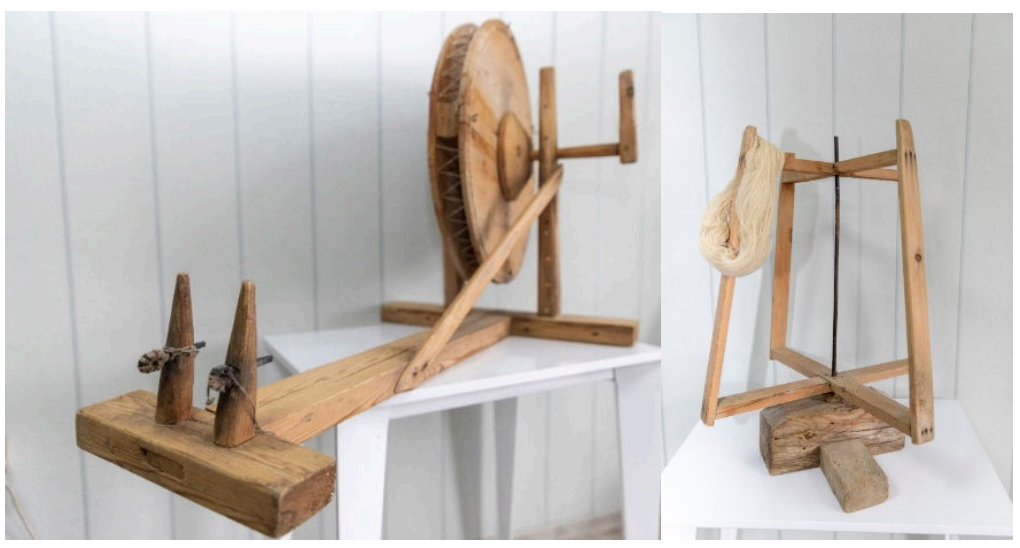

(Eroğlu, 2021) 


\section{Görsel 6}

Tarak

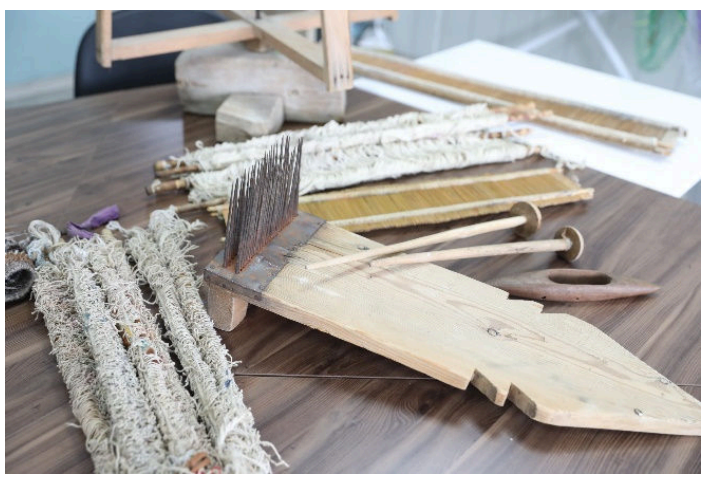

(Eroğlu, 2021)

\subsection{Karnavas Bezi Dokuma Tekniği}

\section{Çizim1}

Bezayağı Dokuma

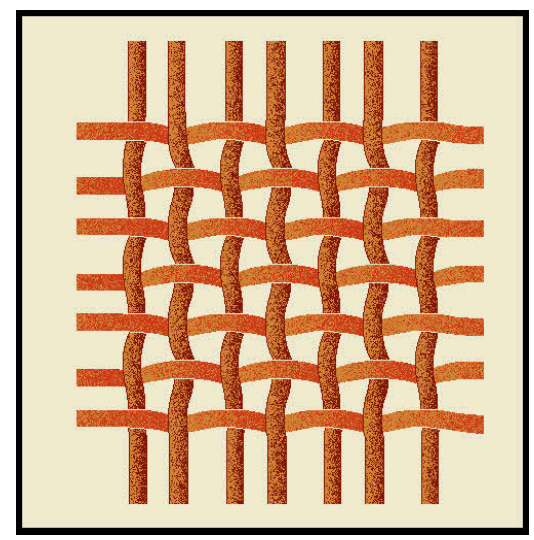

(Eroğlu, 2021)

Çile halinde alınan pamuk ipin dokumaya hazırlanmasının meşakkatli olmasından dolayı köy kadınları bu aşamaları terk etmiş fabrikasyon $\% 100$ pamuk iplikleri tercih etmeye başlamıştır. Günümüzde pamuk ip $60 \mathrm{~cm}$. en olacak şekilde leventlere sarılı şekilde gelir. Leventler kamçılı tezgahların üst kısmında kendileri için ayrılmış özel alana yerleştirilir. Leventlerde sarılı olan pamuk iplikler tek tek alınır. Bu ipliklere "çözgü ipi” denir. Karnavas bezi çözgü iplikleri, her bir kücü deliğinden tek geçirilir, her bir tarak deliğinden çift geçirilir ve "silmin" denen tahta çubuğa bağlanır. Yapılan bu işleme tarak-kücü almak (tahar işleme) denir. Yün ipliklerde de tarak-kücü almak (tahar işleme) aynı şekilde yapılır. İpin kalınlığına göre $\mathrm{cm}$. ye düşen tarak dişs sayısı değişir. İpin kalınlığına göre tarak değiştirilir. Karnavas Bezi pamuklu dokumada 10'luk tarak kullanılır. Karnavas Bezi yün dokumasında ise 8'lik tarak kullanılır. Karnavas bezi kamçılı tezgahlarda bezayağ 1 tekniği ile dokunur. Karnavas Bezi dokunmuş iki parçadan oluşur. 160x $55 \mathrm{~cm}$. boyutunda dokunmuş iki parçanın elde dikilmesi ile toplamda 160x110 $\mathrm{cm}$. ebatına ulaşan bir bezdir. El dokuması olduğu için dokuma ölçülerinde değişiklikler görülebilir.

\subsection{Karnavas Dokumalarında Kullanılan Motifler}

Motifler insanın tarihi geçmişinde şekillenen duygu ve düşüncelerini günümüze yansıtır. Orta Asya'da Türklerin yaşadığı bölgelerde ortaya çıktığı ve geliştiği kabul edilen dokuma geleneği, Selçuklular yoluyla Anadolu'ya gelmiş ve gelişimini burada sürdürmüştür. Türkler Anadolu'ya geldiklerinde, Orta Asya'daki dokuma geleneğine dayanan engin bir dokuma kültürüne sahiptiler. Bu dokuma geleneklerini burada da devam ettirmişlerdir. Karnavas yöresi dokumaları da bu kültürün devamını sağlayan yörelerden biridir. Yaşamın gerekliliği olarak ortaya çıkan dokumalar, bu işle uğraşanların yaratıcılığı ile zenginleşmiştir. Dokuyan kadının iç dünyası, çeşitli renk ve desenlere yansımıştır. Bu nedenle motif ve kompozisyonlar belirli bir anlatıma yönelik mesaj verir. Saadet, uğur, aşk, sevgili, dedikodu, bereket, nazar, evlilik, çocuk motifleri belirli bir anlatıma yöneliktir. Üzüntüsünü, sevincini, hasretini, acısını, beklentisini, arzusunu dokumasına işler. Sadece çizgi ve şekiller değil renklerde adeta konuşur. Kırmızı aşktır, yeşil murattır, mavi umuttur, beyaz mutluluk, siyah matemdir. 


\subsubsection{Elibelinde Motifi (Em damgast)}

Kadını sembolize eder. Anadolu dokumalarında değişik formlarda sıklıkla görülmektedir. Kadın, insanlı̆̆ın ince, duyarlı, şefkatli, becerikli yönünü simgelemekte doğurganlı̆̆ı çoğunlukla Elibelinde motifi ile temsil etmektedir. Bu motif, annelik, doğurganlıkla özdeşleştiği gibi çocukları korumak, yaşatmak gibi kutsal uğraşların simgesi olup, çok çocuk sahibi olmak, evine bereket getirmek gibi düşüncelerin de göstergesidir. Bu motif sadece analık ve doğurganlığı değil, aynı zamanda kısmet, bereket, uğur ve mutluluğu da simgeler.Elibelinde motifi Olur ve Oltu yöresi'nde "Kolubeldeki ayel" ismini almaktadır.

\subsection{2. Çengel}

Nazarla ilgili bir motif olup bazı yörelerde "çakmak, eğri ala, balık" gibi isimlerle anılır (Görsel 10).

\subsubsection{Ylldiz}

Yıldız ışığın sembolüdür. Işık ise aklı simgeler. Anadolu dokumalarında mutluluk, iyilik, aydınlık, ş̧ık ve kahramanlı̆̆ simgeler. Dokumadaki zorluğu nedeniyle 5 köşeli yıldıza nadir rastlanır. Genellikle 8 veya daha çok köşeli yıldızlar yaygındır.

\subsubsection{Göz Motifleri}

İnsan gözünün kem bakışlara karşı en iyi koruyucu olduğu inancından doğmuştur. Kötü gözle bakışın kökeni ve çıkış noktası insan gözüdür. Günlük yaşamda kullanılan dokumada sık sık işlenmiştir. En yaygın olanı dörde bölünmüş eş kenar dörtgen şeklindedir. Kare, eşkenar dörtgen ve dikdörtgen şeklinde göz motifine de rastlanır. Göz motifi yörelere göre değişkenlik gösterir.

\subsubsection{Su Yolu}

Su, insanlar için en önemli ihtiyaçtır. Bu motifi insanlar her zaman kullanmışlardır. Kurak bölgelerdeki türbelerin birçoğunun kubbesinde suyolu motifi görülür. Bu motifler yapıldıkları veya üretildikleri malzemenin türüne göre değişiklik gösterirler.

\subsubsection{Pıtrak (Kırkıtlı Gül)}

Tarlalarda bulunan, dikenleri ile insanlara ve hayvanlara yapışan bir bitkidir. Üzerindeki dikenlerin kötü gözü uzaklaştırdığına inanan Anadolu insanı, onu nazarlık motifi olarak kullanmışlardır. Pıtrak gibi deyimi, ağaçlardaki bolluğu anlatır. Bu motif bereket simgesi olarak genellikle un çuvallarında kullanılır.

\subsubsection{Hayat Ăgact}

Ölümsüzlük ve soy ile ilgili motiflerden olan hayat ağacı, sonsuz yaşamı ve cenneti simgeler. Tek tanrılı dinlerde, yaratılışı anlatan bölümlerdeki ortak nokta ağaçtır. Bazı motiflerde bu ağacı bir yılanın beklediği görülür. Cennetteki yasak ağacın meyvesinden Havva'ya veren yılan, böylece Korkut Ata'dan Gılgamış'a ve Büyük İskender'e kadar tüm ölümsüzlüğü arayanların bu otu bulmalarına ve yemelerine engel olmuştur. Ölümsüzlüğü bulamayan insanlar, ölümden sonraki hayat ile umutlarını sürdürürler. Ve bu hayat ağacı ile simgelenir. Şaman inancına göre hayat ağacı, dünyanın eksenidir. Orta Asya inancına göre kâinat, hayat ağacı, yer, gök ve gezegenlerle temsil edilir. Gök ve yeri bağlayan hayat ağacıdır (Öney,1968, s. 117). Meyveli hayat ağacı motifi, ev bereket bulsun anlamındadır. İlk çağlardan beri değişik görünümlerle taşlara işlenen hayat ağacı motifi yapraklı ise uzun ömürlülük, çiçekli ise, güzellik artırımı anlamlarını taşır. İslam dini, sanatçıyı bitki motiflerine yönlendirmiş, bu motiflerde bile gerçekçilikten kaçınılarak bir soyutlamaya gidilmiştir. Bazen yalnızca dolgu amaçlı olan bu motifler, bazen de sembolik nitelikte olurlar (Ergüder, 2007, s. 147).

\subsection{8. Çiçek-Yaprak Motifi}

Bazı araştırmacılar, verimlilik, üreme, bereket ve ulaşılmak istenen şeye kavuşma için adak olarak kullanıldığını vurgularlar. Pek çok çiçeğin farklı anlamları vardır. Lalenin yazılışı, "Allah" kelimesine benzemesinden dolayı bu çiçeği anlamlı kılar. Gülün peygamberimizi temsil ettiği kökleri ölümsüzlüğü sapı hayatı sembolize eden Nilüfer çiçeği (Lotus) nin ise geleceğin ve bu anın simgesi olarak kullanılır (Karamağaralı, 1998, s. 36).

\subsection{Karnavas Bezi Örnekleri}

Ormanağzı (Karnavas) köyünün 94 yaşındaki en yaşlı bireyi Şahinder KALKAN 'la yapılan görüşmede, annesi ve anneannesinin de bu dokumayı dokuduğunu ve kendisinin de onlardan öğrendiğini söylemiştir. Karnavas bezi çevre hiçbir köyde dokunmamış sadece Ormanağzı (Karnavas) köyünde dokunarak yiyecek veya giyecek karşıllığında çevre köylere satıldığını belirtmiştir. 


\section{Görsel 7}

Karnavas Başörtüsü Şahinder Kalkan

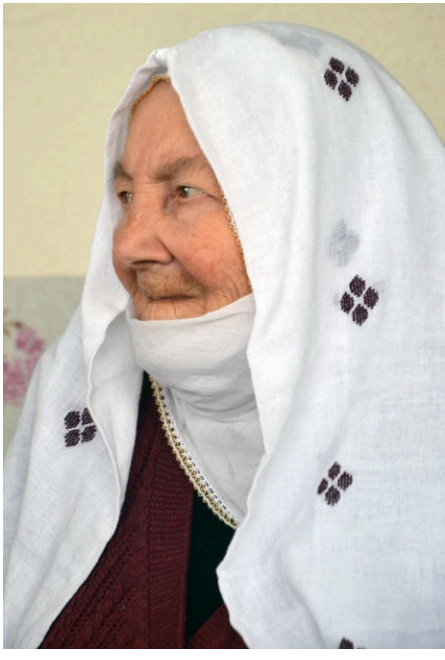

(Keskin, 2021)

\section{Görsel 8}

Yün Dokuma Karnavas Bezi

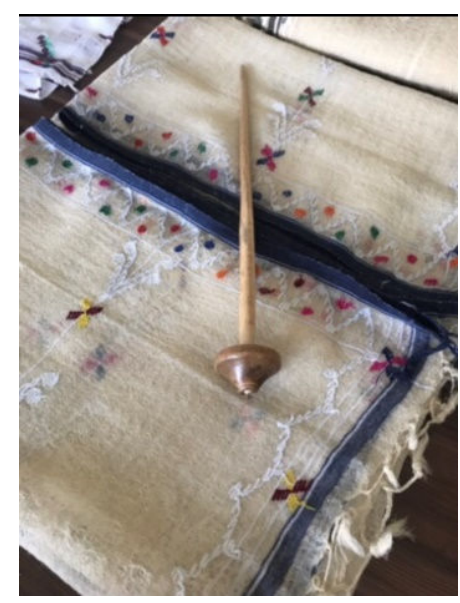

(Keskin, 2021)

\section{Görsel 9}

Pamuk Dokuma Karnavas Bezi

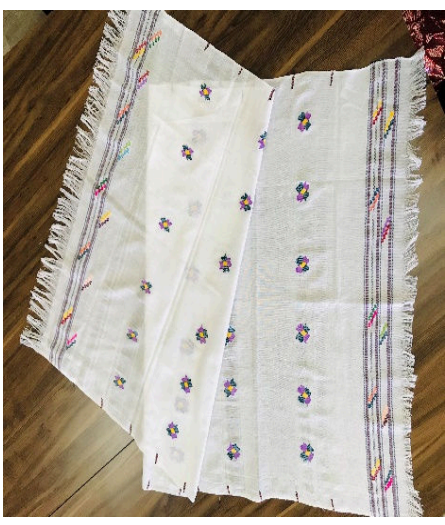

(Keskin, 2021) 


\section{Görsel 10}

Karnavas Bezi Motifleri

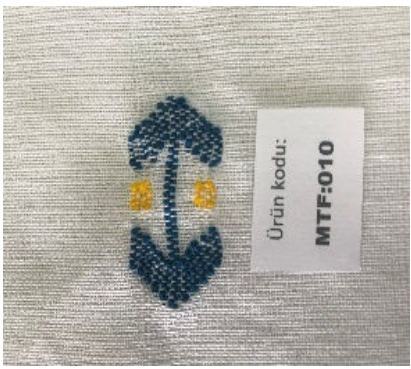

Şemsiye

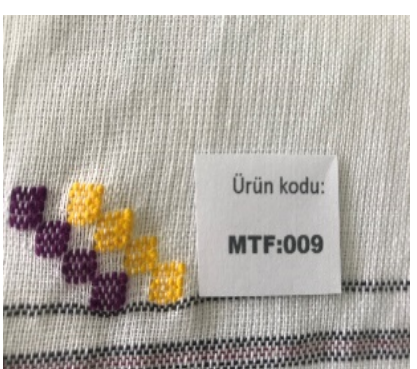

Meryem Ana

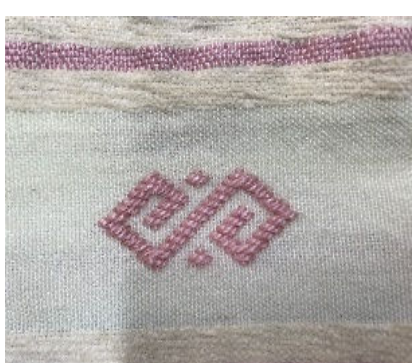

Çengel

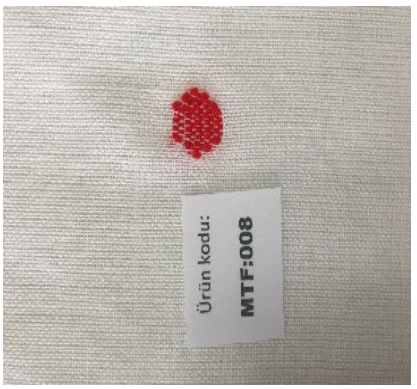

Tekli Para Çiçeği

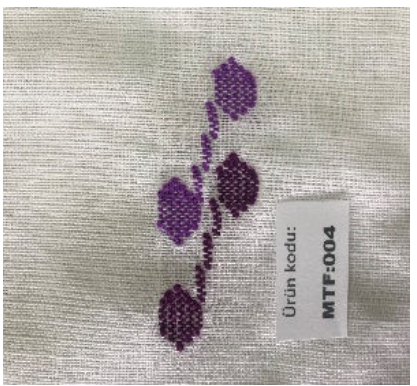

İkili Salkım

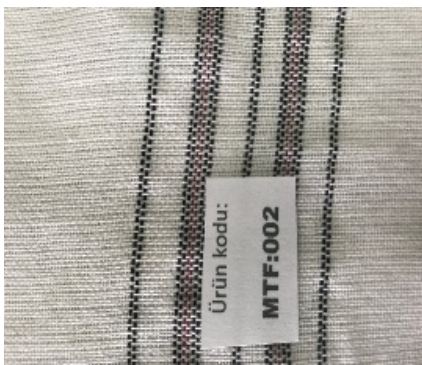

$\mathrm{Su}$

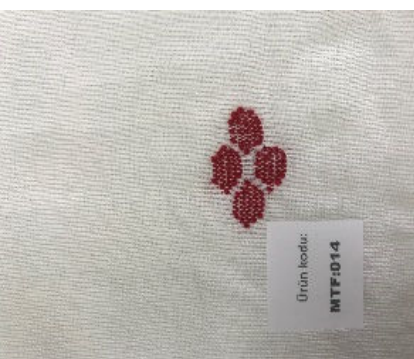

Dörtlü Para Çiçeği

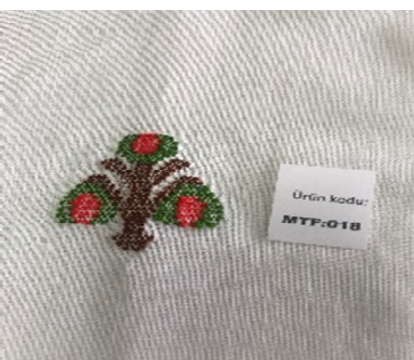

Hayat Ağacı

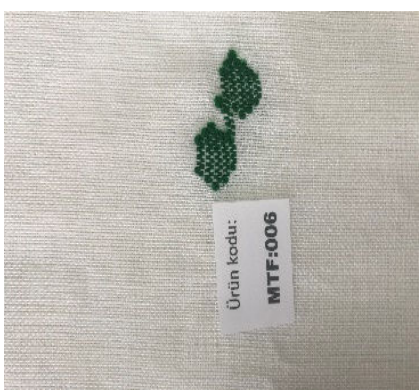

Çiftli Para Çiçeği

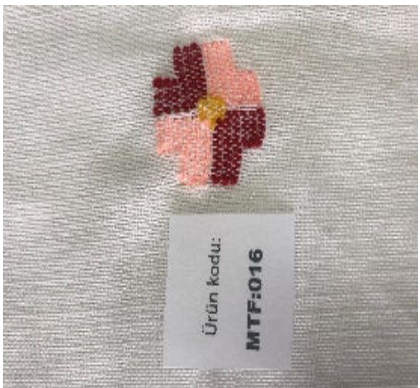

Gelin Alma

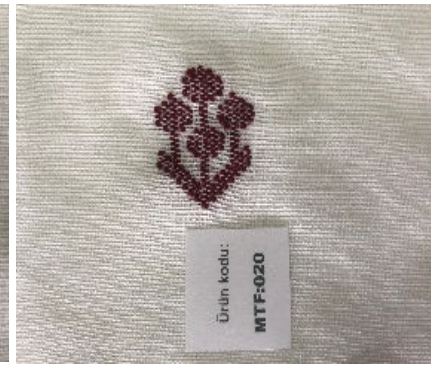

Dörtlü Saz Dalı

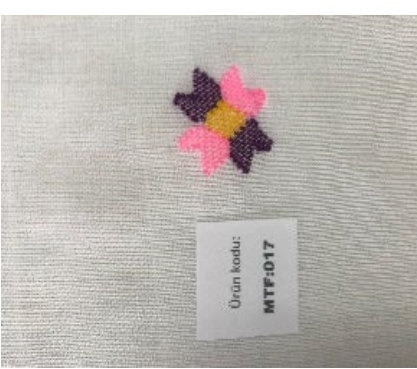

Y1ldiz

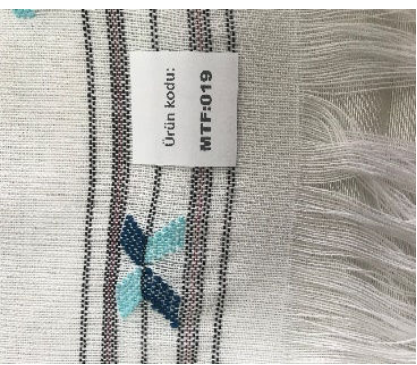

Su ve Çatal Çiçek

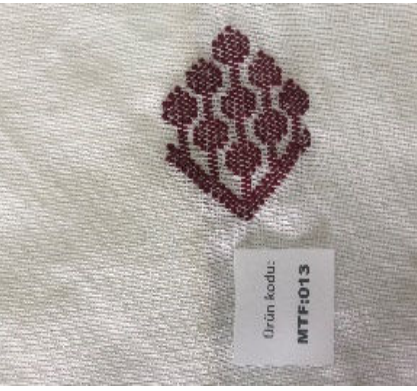

Dokuzlu Saz Dalı

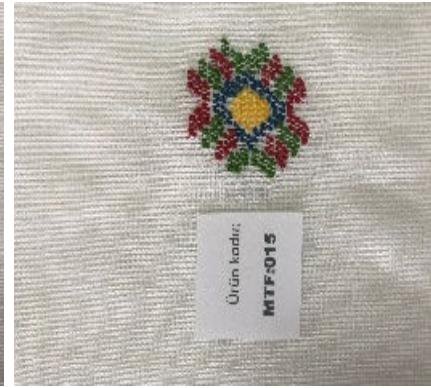

Kırkıtlı Gül (Pıtrak)

(Eroğlu, 2021) 


\section{Görsel 11}

Olur Kaymakamı İlker Eker, Olur Belediye Başkanı Sıddık Demircan Desteği İle Açılan Karnavas Bezi Dokuma Atölyesi (2021)

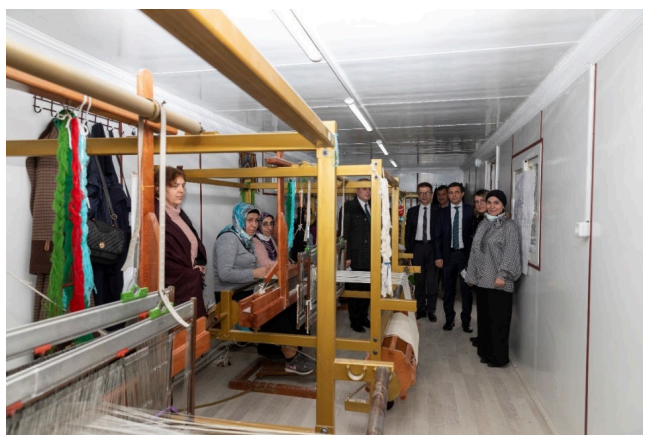

(Eroğlu, 2021)

\section{Görsel 12}

Dokuma Yapan Karnavas'lı Bayanlar

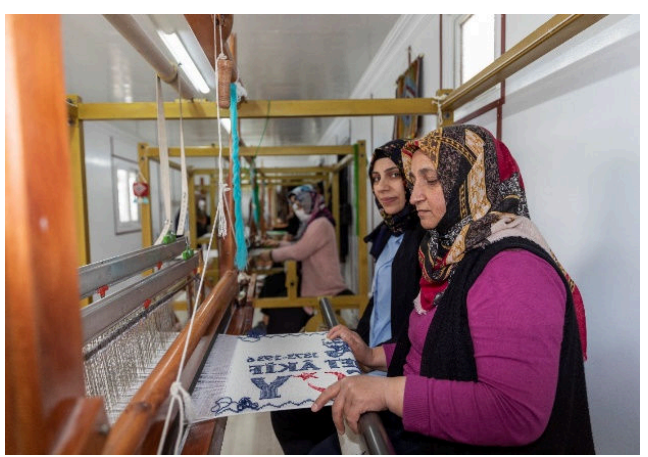

(Eroğlu, 2021)

\section{Görsel 13}

Karnavas Bezi Dokuma Tezgahlarl

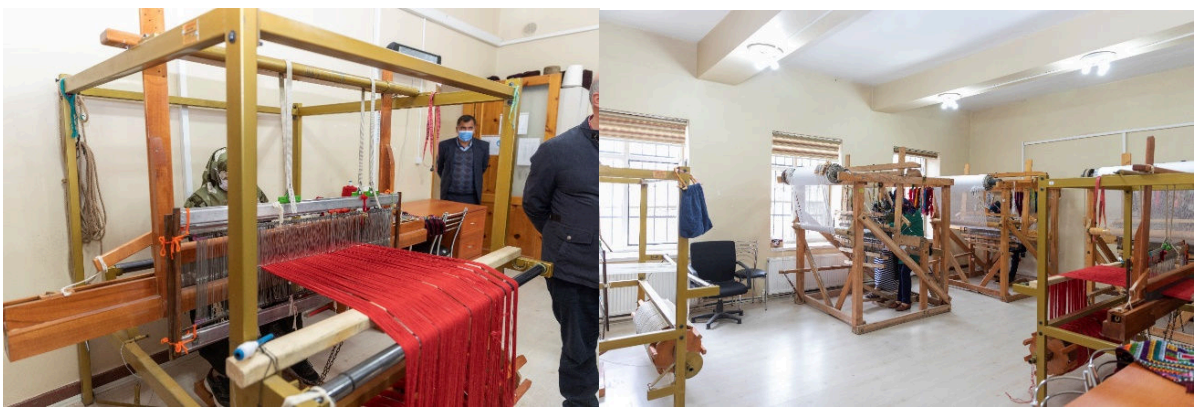

(Eroğlu, 2021)

\section{Görsel 14}

Karnavas Bezi Ön ve Arka Yüzü

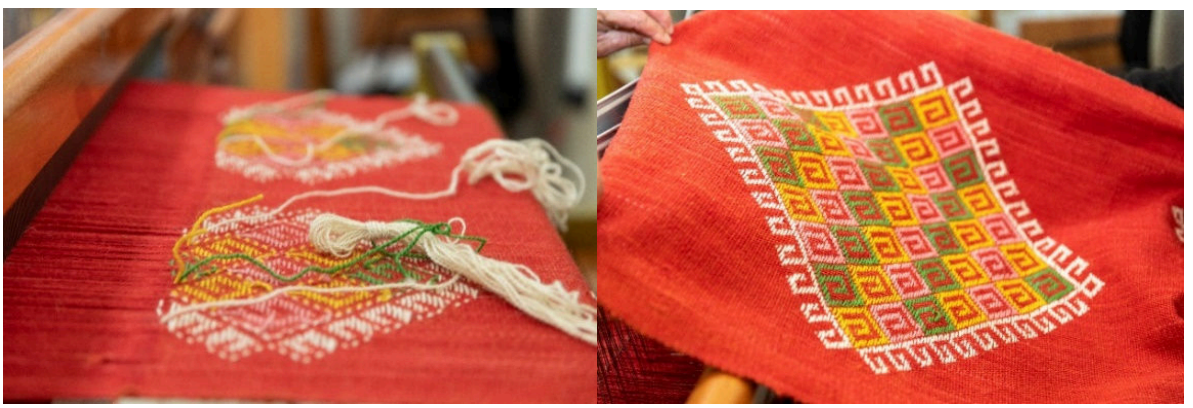

(Eroğlu, 2021) 


\section{Görsel 15}

Karnavas Bezi

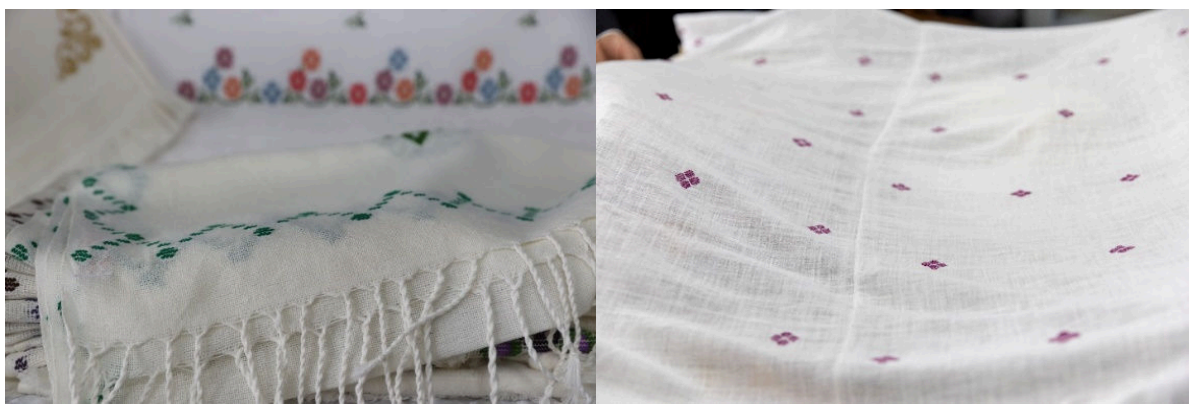

(Eroğlu, 2021)

\section{Görsel 16}

Ŭ̆ur Böceği Desenli Karnavas Bezi

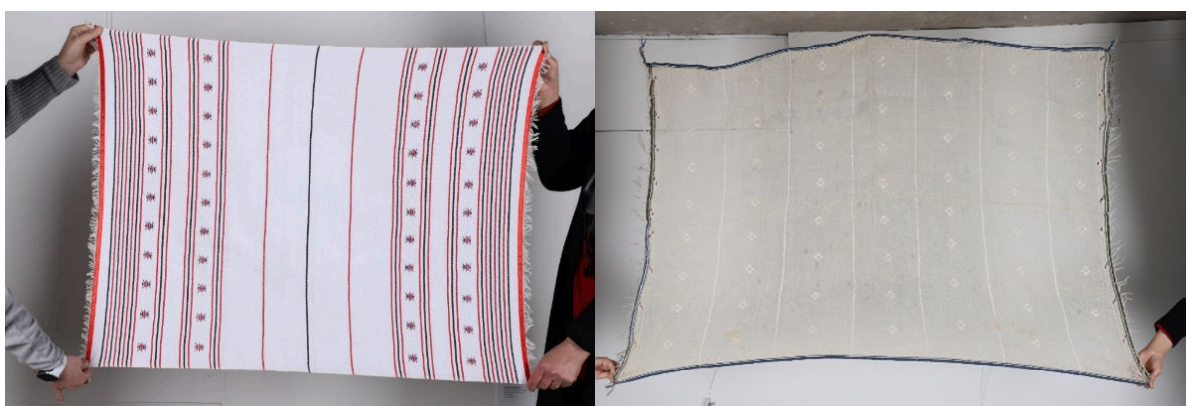

(Çomaklı, 2008)

\section{Görsel 17}

Karnavas Bezi Dokumasl Örtü

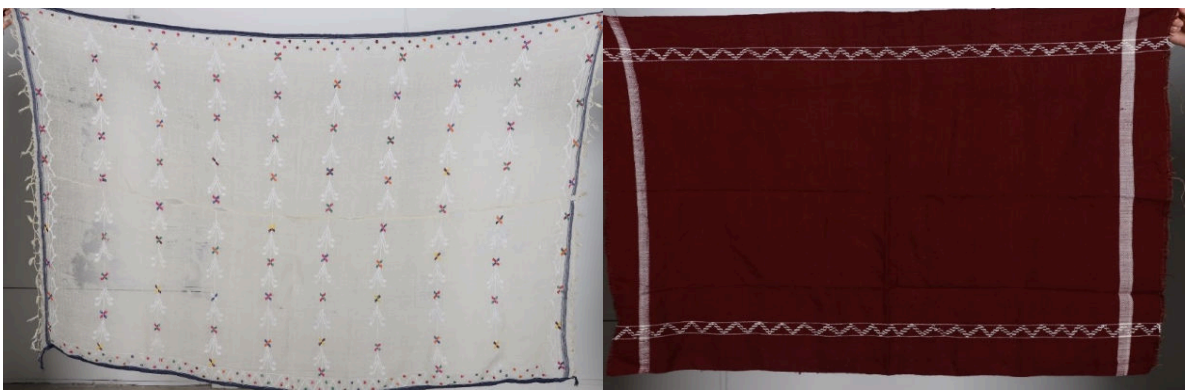

(Eroğlu, 2021)

\section{Görsel 18}

Karnavas Bezi Dokuması Örtü

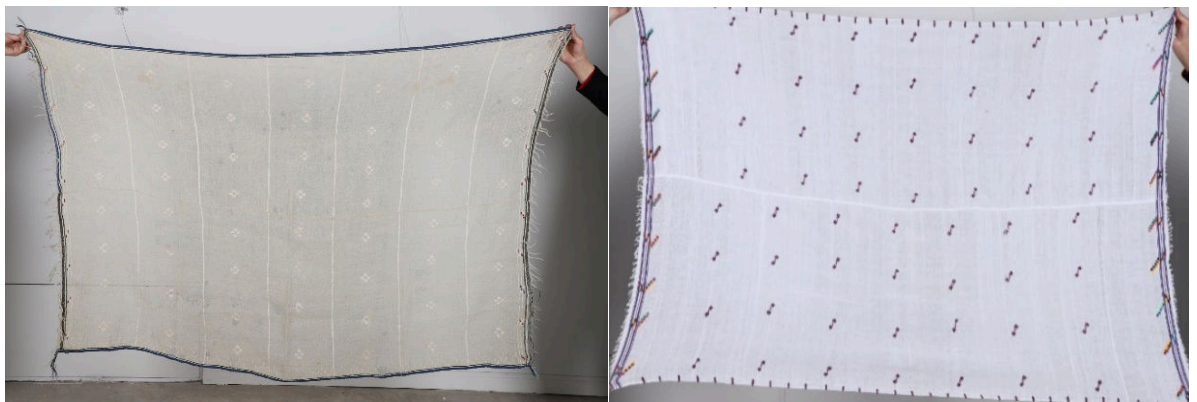

(Eroğlu, 2021) 


\section{Görsel 19}

Fular

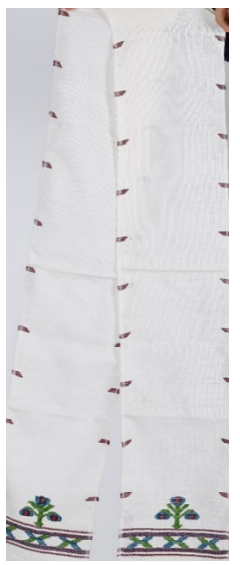

(Eroğlu, 2021)

\section{Görsel 20}

Yünden Yapılan Karnavas Ehramı 200x $370 \mathrm{Cm}$.

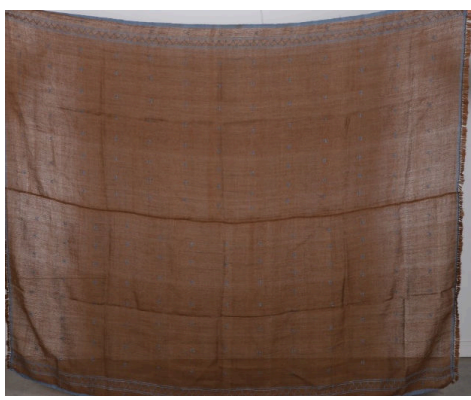

(Eroğlu, 2021)

\section{Sonuç}

Yaklaşık 200 yıllık geçmişe sahip Karnavas Bezi yöre kadınları tarafından örtünme amaçlı kullanılmaktadır. Teknik, malzeme ve desen açısından benzer Anadolu dokuma özelliklerini taşımasının yanısıra geleneksel özellikleri de bünyesinde barındırması açısından önem arzetmektedir. Dokumasının pamuklu ve görsel açıdan zengin olması sedeniyle günümüzde farklı alanlarda da kullanılmaya başlanmıştır. Tunik, yelek, fular, yenidoğan seti gibi ürünler için Karnavas bezi dokunmuş ve dikilmiştir. Masa örtüsü, runner, perde dokunarak Karnavas bezinden üretilmiş yeni ürünlerin ortaya çıkması sağlanmıştır. Araştırmalar neticesinde yöre halkının motiflerin anlamlarını bilmediği, başörtüsü olarak sadece yaşlıların kullanmaya devam ettiği görülmektedir. Olur Kaymakamı İlker Eker, Olur Belediye Başkanı Sıddık Demircan, büyük emek veren Reyhan Keskin desteği ile Halk Eğitimi Merkezi nde Karnavas Bezi Dokuma Atölyesi kapsamında köyde çalışmalar yapılmaktadır. Yöresel özelliği bulunan kültürel mirasımız Karnavas Bezi’ nin tanıtımının yapılması, coğrafi işaret alımının sağlanması, yerel yönetimler ve üniversite işbirliği ile sürdürebilir projeler devam etmeli hem yöre kültürünün tanıtılması hem ekonomik açıdan desteklenmesi yönünde çalışmalar yapılmalıdır.

\section{Kaynakça}

Çomaklı, Z. (2008). Anam başka bağlar bacım bir başka: Erzurum oyaları. Aktif Yayınevi.

Ergüder, A. A. (2007). Çoruh vadisinde düz dokumalar. Oltu Ticaret ve Sanayi Odası.

Eroğlu, A. A. (2021). Karnavas ile ilgili görseller [Fotoğraf]. Ayşe Aslıhan Eroğlu Kişisel Arşivi.

Karamağaralı, B. (1998) “Ejder ve Lotus Motifinin Halı Seccadelerdeki İkonografisi”, Arış, , 17-26.

Keskin, R. (2021). Karnavas ile ilgili görseller [Fotoğraf]. Reyhan Keskin Kişisel Arşivi.

Öney, G. (1968). “Artuklu Devrinden Bir Hayat Ağacı Kabartması Hakkında”, Vakıflar Dergisi, 7, 117-120. http://babacankütüphanesi.com/Dergi/dergi.php?Dergi=\%27Vakiflar\%27

Salman, F. (2011). Yerel bir tekstil ürünü: Karnavas bezi ve teknik özellikleri. Sanat Dergisi, 18, 51-62. https://dergipark.org.tr/tr/download/article-file/29011 